\title{
Difficultness-Usefulness Pyramid (DUP) Sebagai Metode Baru untuk Memilih Elemen yang Diprioritaskan dalam Manajemen e-Learning Kesehatan
}

\author{
Heru Santoso Wahito Nugroho ${ }^{1}$, Sahrir Sillehu ${ }^{2}$, Handoyo ${ }^{1}$, Suparji ${ }^{1}$, Sunarto ${ }^{1}$, \\ Subagyo $^{1}$, Bambang Sunarko ${ }^{1}$, Bahtiar ${ }^{3}$ \\ ${ }^{1}$ Politeknik Kesehatan Kemenkes Surabaya/ Forum Ilmiah Kesehatan (FORIKES) \\ ${ }^{2}$ Sekolah Tinggi Ilmu Kesehatan Maluku Husada/ Forum Ilmiah Kesehatan (FORIKES) \\ ${ }^{3}$ Politeknik Kesehatan Kemenkes Makassar/ Forum Ilmiah Kesehatan (FORIKES)
}

Pre-print/ versi Indonesia untuk artikel di International Journal of Public Health Research and Development (IJPHRD), Volume 9 Number 2, February 2018.

\begin{abstract}
ABSTRAK
Pada era informasi seperti sekarang ini, pada umumnya institusi-institusi kesehatan telah memanfaatkan teknologi informasi dan komunikasi dalam berbagai kegiatan organisasi, salah satunya adalah e-learning sebagai pendukung kegiatan pendidikan tenaga kesehatan. Penelitian ini bertujuan untuk menciptakan metode baru untuk memilih elemen-elemen e-learning pendidikan tenaga kesehatan yang diprioritaskan untuk diperbaiki, dengan menggunakan lima langkah yaitu: pemilihan elemen-elemen, pemilihan atribut-atribut, penentuan metode penentuan prioritas, uji coba di lapangan, penarikan kesimpulan dan pengajuan rekomendasi. Hasil penelitian menunjukkan bahwa: 1) elemen yang terpilih adalah learning design, handout, book, link to resources, discussion forum, chatting, assignment, feedback, quiz dan survey; 2) atribut yang terpilih adalah difficultness dan usefulness; 3) prioritas ditentukan berdasarkan range yang dimulai dari mean score of difficultness sampai dengan mean score of usefulness, 4) berdasarkan hasil uji coba divisualisasikan urutan elemen berdasarkan range dalam bentuk "piramida", secara berurutan mulai dari range terbesar adalah assignment, quiz, feedback, discussion, link to resources, book, survey, learning design, handout, and chatting, 5) lima elemen yang menjadi prioritas untuk diperbaiki terlebih dahulu adalah assignment, quiz, feedback, discussion and link to resources. Selanjutnya disimpulkan bahwa metode baru ini bisa diterapkan dengan mudah untuk memilih komponenkomponen yang diprioritaskan dalam upaya perbaikan e-learning pendidikan tenaga kesehatan.
\end{abstract}

Kata kunci: Difficultness-Usefulness Pyramid, e-Learning kesehatan, Manajemen

\section{PENDAHULUAN}

Pada era informasi seperti sekarang ini, pada umumnya institusi-institusi kesehatan seperti dinas kesehatan, rumah sakit, klinik kesehatan dan institusi pendidikan tenaga kesehatan telah memanfaatkan teknologi informasi dan komunikasi (TIK) dalam berbagai kegiatan organisasi. Salah satu pemanfaatan TIK di lembaga pendidikan tenaga kesehatan adalah sebagai pendukung utama dalam penerapan pembelajaran yang dikenal dengan electronic learning (e-Learning). ${ }^{(1)}$

Kemajuan pendidikan tenaga kesehatan dalam berbagai jenis dan jenjang akan sangat menentukan kualitas tenaga kesehatan yang dihasilkan. Untuk itulah keyakinan akan pentingnya kemajuan proses pendidikan tenaga kesehatan harus benar-benar 
dianggap penting oleh pengelola institusi pendidikan. Apalagi dalam era informasi, arus informasi menjadi sangat cepat menembus seluruh penjuru dunia. Tanpa bisa mengikuti perkembangan dunia pendidikan yang tersebar melalui perkembangan teknologi informasi dalam era ini, institusi pendidikan kesehatan kita akan tertinggal jauh. Sebaliknya jika institusi pendidikan kesehatan kita dapat mengikuti perkembangan global, maka lompatan kemajuan yang didapatkanpun akan jauh ke depan pula. ${ }^{(2)}$

Di Indonesia sebagai negara yang sedang berkembang, masih banyak lembagalembaga pendidikan tenaga kesehatan yang belum mengimplementasikan e-learning sebagai program pembelajaran. Sementara itu, lembaga-lembaga yang telah mengimplementasikan e-learning, masih banyak yang belum dapat menjalankannya secara optimal. Para dosen yang seharusnya berperan sebagai sebagai manajer pembelajaran bagi mata kuliah yang diampunya, masih banyak yang mengalami kesulitan secara teknis dalam pengelolaan e-learning. Hal ini akan membuat sistem $e$ learning belum siap sepenuhnya untuk digunakan. Dengan demikian, mahasiswa sebagai konsumen terpaksa menggunakan sistem e-learning yang sesungguhnya belum disiapkan dengan sempurna. ${ }^{(2)}$

Mengacu kepada Moodle sebagai free e-learning software yang banyak digunakan di Indonesia, termasuk dalam pendidikan tenaga kesehatan seperti sekolah kedokteran, keperawatan, farmasi, kesehatan masyarakat dan sebagainya, ada beberapa komponen pokok dalam e-learning yang harus dikelola oleh dosen selaku penanggung jawab mata kuliah dan digunakan secara bersama-sama dengan para mahasiswa. Komponenkomponen pokok tersebut terdiri atas desain pembelajaran, handout atau file bahan ajar, book, link ke sumber belajar, forum diskusi, chatting, penugasan, feedback, quiz, dan survey. E-learning yang ideal mempersyaratkan bahwa seluruh komponen di atas telah disiapkan dan bisa dioperasikan dengan baik. ${ }^{(3)}$

Hasil studi pendahuluan melalui wawancara kepada beberapa dosen dan mahasiswa di Poltekkes Kemenkes Surabaya sebagai salah satu lembaga pendidikan tenaga kesehatan di Indonesia menunjukkan bahwa sebagian besar dari mereka menyatakan bahwa belum mahir dalam menjalankan e-learning. Seluruh dosen yang diwawancarai menyatakan bahwa desain pembelajaran masih dibuatkan oleh administrator website dan mereka tinggal mengisi topik-topik pembelajaran untuk satu semester. Komponen yang telah dikuasai dengan baik oleh para dosen adalah penyiapan file bahan ajar dan pembuatan link sumber belajar, sedangkan penyediaan buku, pembuatan forum diskusi, chatting, penugasan, feedback, quiz dan survey belum dapat dijalankan dengan lancar. Sementara itu, sebagian besar dari mahasiswa menyatakan bahwa mereka baru mengenal e-learning system dan berniat untuk mempelajarinya, namun mereka mengalami kesulitan karena sebagian besar dosen terkait belum bisa menjadi pemandu yang baik bagi mahasiswa sebagai pengikut mata kuliahnya.

Uraian di atas merupakan salah satu contoh gambaran dari masih lemahnya implementasi e-learning dalam pendidikan tenaga kesehatan di Indonesia. Untungnya, sistem e-learning masih dapat berjalan meskipun tidak seluruh komponen dijalankan oleh dosen dan mahasiswa. Sebagai contoh, meskipun dalam e-learning baru tersedia pemaparan desain pembelajaran dan file bahan ajar, namun para mahasiswa masih dapat memanfaatkan sistem tersebut untuk melihat pokok-pokok pembelajaran dalam satu semester serta mengunduh bahan-bahan ajar yang mereka perlukan.

Permasalahan sebagaimana telah diuraikan di atas tentunya harus menjadi menjadi perhatian penting bagi pengelola sistem e-learning. Telah dijelaskan di atas bahwa $e$ learning tetap bisa berjalan meskipun belum menerapkan seluruh komponen yang ada. 
Dengan demikian manager perlu memilih komponen-komponen yang diprioritaskan untuk diperbaiki penyetelan dan pengoperasiannya, sehingga secara bertahap diharapkan akan semakin banyak jumlah komponen yang bisa dijalankan dengan baik, dan pada gilirannya seluruh komponen dapat dijalankan secara optimal oleh dosen dan mahasiswa sebagai pengguna.

\section{METODE}

Penelitian ini merupakan usaha untuk menciptakan metode baru yang sederhana dalam rangka memilih elemen-elemen e-learning bagi pendidikan tenaga kesehatan berdasarkan urutan prioritas. Penelitian dilakukan pada tahun 2017 di Jurusan Kesehatan Lingkungan, Politeknik Kesehatan Kemenkes Surabaya, Indonesia. Sumbersumber pokok yang dibutuhkan dalam penelitian ini antara lain: 1) literatur-literatur dalam bidang sistem informasi, 2) para pakar sistem informasi, 3) para dosen dalam bidang kesehatan, 4) para mahasiswa bidang kesehatan.

Penciptaaan metode baru ini dilaksanakan dengan beberapa langkah yaitu:

1. Pemilihan elemen-elemen e-learning yang akan diprioritaskan melalui literature review, yang berkaitan dengan e-learning software.

2. Pemilihan atribut-atribut yang digunakan sebagai dasar penentuan prioritas melalui literature review dan pertimbangan para pakar.

3. Penentuan metode pemilihan elemen-elemen e-learning berdasarkan urutan prioritas melalui pertimbangan para pakar.

4. Uji coba metode melalui penelitian lapangan, yang terdiri atas pengumpulan data melalui pengisian kuesioner dan analisis data menggunakan metode statistika deskriptif.

5. Penarikan kesimpulan dan pengajuan rekomendasi berdasarkan hasil analisis data.

\section{HASIL}

\section{Hasil pemilihan elemen-elemen e-learning yang akan diprioritaskan}

Pemilihan elemen-elemen $e$-learning bagi pendidikan tenaga kesehatan yang akan diprioritaskan dilakukan melalui literature review. Dalam hal, ini literatur utama adalah buku-buku panduan open source e-learning software yang paling populer yang merupakan bagian dari Softaculous di dalam cPanel, suatu panel manajemen website yang terkenal. Dalam Softaculous ini tersedia tujuh e-learning software yaitu Chamilo, Claroline, Moodle, eFront, Dokeos, DoceboLMS dan ATutor. Mengacu kepada literaturliteratur di atas, maka dipilih sepuluh elemen utama dalam e-learning yaitu: learning design, handout, book, link to resources, discussion forum, chatting, assignment, feedback, quiz and survey. ${ }^{(3)}$

\section{Hasil pemilihan atribut-atribut e-learning yang digunakan sebagai dasar penentuan prioritas}

Pemilihan atribut-atribut yang digunakan sebagai dasar penentuan prioritas dilakukan melalui literature review dan pertimbangan pakar. Dalam hal ini, literature review diarahkan kepada model teori tentang penerimaan user terhadap implementasi teknologi informasi dalam berbagai sistem, termasuk e-learning. Menurut Surendran 
(2012) salah satu model penerimaan teknologi yang paling banyak digunakan adalah Technology Acceptance Model (TAM) yang dalam hal ini telah berkembang menjadi tiga generasi yaitu TAM, TAM-2, dan TAM- $3^{(4)}$. Dalam TAM ${ }^{(5)}$, TAM- $2^{(6)}$ dan TAM$3^{(7)}$ diperkenalkan dua specific belief yang menjadi determinan dari penerimaan pengguna terhadap teknologi informasi yaitu "perceived usefulness" dan "perceived ease of use". Dalam hal ini, pengguna akan lebih berpeluang untuk menerima implementasi teknologi informasi secara sukarela jika teknologi tersebut dirasakan bermanfaat dan dapat digunakan dengan mudah. Dengan demikian, mengacu kepada kedua atribut di atas, elemen-elemen yang diprioritaskan untuk diperbaiki lebih dahulu adalah elemen-elemen yang masih sulit untuk digunakan tetapi dirasakan lebih bermanfaat atau lebih penting oleh pengguna. Dengan kata lain, elemen-elemen yang diprioritaskan adalah elemen-elemen dengan "ease of use" dan "usefulness" yang tinggi.

Hasil literature review di atas selanjutnya didiskusikan dengan para pakar terkait yang berasal dari dua lembaga ilmiah yaitu "Humanistic Network for Science and Technology" (HNST). Berdasarkan hasil diskusi tersebut, selanjutnya disetujui bahwa "ease of use" dan "usefulness" ditetapkan sebagai atibut yang digunakan sebagai dasar untuk penentuan elemen-elemen yang diprioritaskan dalam peningkatan kualitas $e$ learning dalam pendidikan tenaga kesehatan. Dalam hal ini juga disepakati bahwa terminologi "ease of use" diubah menjadi "difficultness" dengan pertimbagan untuk memudahkan penerapannya dalam praktik.

\section{Hasil penentuan metode pemilihan elemen-elemen yang diprioritaskan}

Kedua atribut yang telah ditetapkan (difficultness dan usefulness) selanjutnya digunakan sebagai dasar untuk memberikan bobot bagi masing-masing elemen $e$ learning pendidikan tenaga kesehatan. Difficultness memiliki sifat negatif, dalam arti bahwa semakin tinggi difficultness maka skor yang diperoleh menjadi semakin negatif. Di sisi lain, usefulness bersifat positif, dalam arti bahwa semakin tinggi usefulness maka skor yang diperoleh menjadi semakin positif. Dengan demikian, diberikan skor negatif untuk difficultness dan skor positif untuk usefulness. Dalam hal ini digunakan rentang 10 dalam bentuk semantic differential untuk rancangan instrumen sebagai berikut:

Tabel 1. Instrumen pemilihan elemen-elemen e-learning berdasarkan prioritas

\begin{tabular}{|c|c|c|}
\hline Difficultness & Elements & Usefulness \\
\hline High -10 - $-9-8-7-6-5-5-4-3-2-10$ Low & Learning design & Low $012345678910 \mathrm{High}$ \\
\hline High - $10-9-8-7-6-5-4-3-2-10$ Low & Handout & Low $012345678910 \mathrm{High}$ \\
\hline High -10 - $-9-8$ - -7 - -6 - -5 - $-4-3-2-2-10$ Low & Book & Low $012345678910 \mathrm{High}$ \\
\hline High - $10-9-9-7$ - -6 - -5 - $-4-3-2-2-10$ Low & Link to resou & Low $012345678910 \mathrm{High}$ \\
\hline High - $10-9-8$ - -7 - -6 - -5 - $-4-3-2-10$ Low & Discussion & Low $012345678910 \mathrm{High}$ \\
\hline High - $10-9-8-7-6-5-4-3-2-10$ Low & Chatting & Low $012345678910 \mathrm{High}$ \\
\hline High - 10 - -9 - -8 - -7 - -6 - -5 - -4 - -3 - -2 - 10 Low & Assignment & Low $012345678910 \mathrm{High}$ \\
\hline High - $10-9-8-7-6-5-4-3-2-10$ Low & Feedback & Low $012345678910 \mathrm{High}$ \\
\hline High - $10-9-8-7-6-5-4-3-2-10$ Low & Quiz & Low $012345678910 \mathrm{High}$ \\
\hline High -10 - $9-8-7-7-6-5-4-3-2-10$ Low & Survey & Low $012345678910 \mathrm{High}$ \\
\hline
\end{tabular}




\section{Hasil uji coba melalui penelitian lapangan (pengumpulan data dan analisis data)}

Pada tahap ini dilakukan pengumpulan data menggunakan instrumen sebagaimana ditampilkan dalam Tabel 1. Responden diminta untuk mengisi instrumen (kuesioner) tersebut dengan dipandu secara langsung oleh peneliti. Selanjutnya dilakukan pengecekan ketepatan dan kelengkapan pengisian seluruh kuesioner dan dilanjutkan dengan data entry secara terkomputerisasi. Tahap berikutnya adalah melakukan analisis data secara deskriptif yaitu menghitung mean score dari difficultness dan usefulness untuk masing-masing elemen dari e-learning, serta menghitung range yang dimulai dari mean score difficultness sampai dengan mean score usefulness. Hasil dari analisis data secara deskriptif ini ditampilkan pada Tabel 2. Selanjutnya range dari masing-masing elemen e-learning disusun secara berurutan mulai dari yang terkecil sebagaimana ditampilkan pada Tabel 3. Terakhir, range yang telah diurutkan ini disajikan dalam bentuk priramida (seperti piramida penduduk) supaya lebih mudah untuk dipahami (Gambar 1). Tampak bahwa range terbesar berada pada posisi paling bawah, sedangkan range terkecil berada pada posisi paling atas.

Tabel 2. Mean Score and Range

\begin{tabular}{cccc}
\hline $\begin{array}{c}\text { Mean Score of } \\
\text { Difficultness }\end{array}$ & Elements & $\begin{array}{c}\text { Mean Score of } \\
\text { Usefulness }\end{array}$ & Range \\
\hline-1.35 & Learning design & 6.99 & 8.34 \\
-1.40 & Handout & 6.80 & 8.20 \\
$-2,00$ & Book & 9.77 & 11.77 \\
-3.01 & Link to resources & 9.80 & 12.81 \\
-5.01 & Discussion & 8.50 & 13.51 \\
-2.00 & Chatting & 2.67 & 4.67 \\
-9.88 & Assignment & 8.88 & 18.76 \\
-8.22 & Feedback & 7.11 & 15.33 \\
-8.88 & Quiz & 8.00 & 16.88 \\
-4.73 & Survey & 7.00 & 11.73 \\
\hline
\end{tabular}

Tabel 3. The Rank of Mean Score Based on Range

\begin{tabular}{cccc}
\hline $\begin{array}{c}\text { Mean Score of } \\
\text { Difficultness }\end{array}$ & Elements & $\begin{array}{c}\text { Mean Score of } \\
\text { Usefulness }\end{array}$ & Range \\
\hline-2.00 & Chatting & 2.67 & 4.67 \\
-1.40 & Handout & 6.80 & 8.20 \\
-1.35 & Learning design & 6.99 & 8.34 \\
-4.73 & Survey & 7.00 & 11.73 \\
$-2,00$ & Book & 9.77 & 11.77 \\
-3.01 & Link to resources & 9.80 & 12.81 \\
-5.01 & Discussion & 8.50 & 13.51 \\
-8.22 & Feedback & 7.11 & 15.33 \\
-8.88 & Quiz & 8.00 & 16.88 \\
-9.88 & Assignment & 8.88 & 18.76 \\
\hline
\end{tabular}




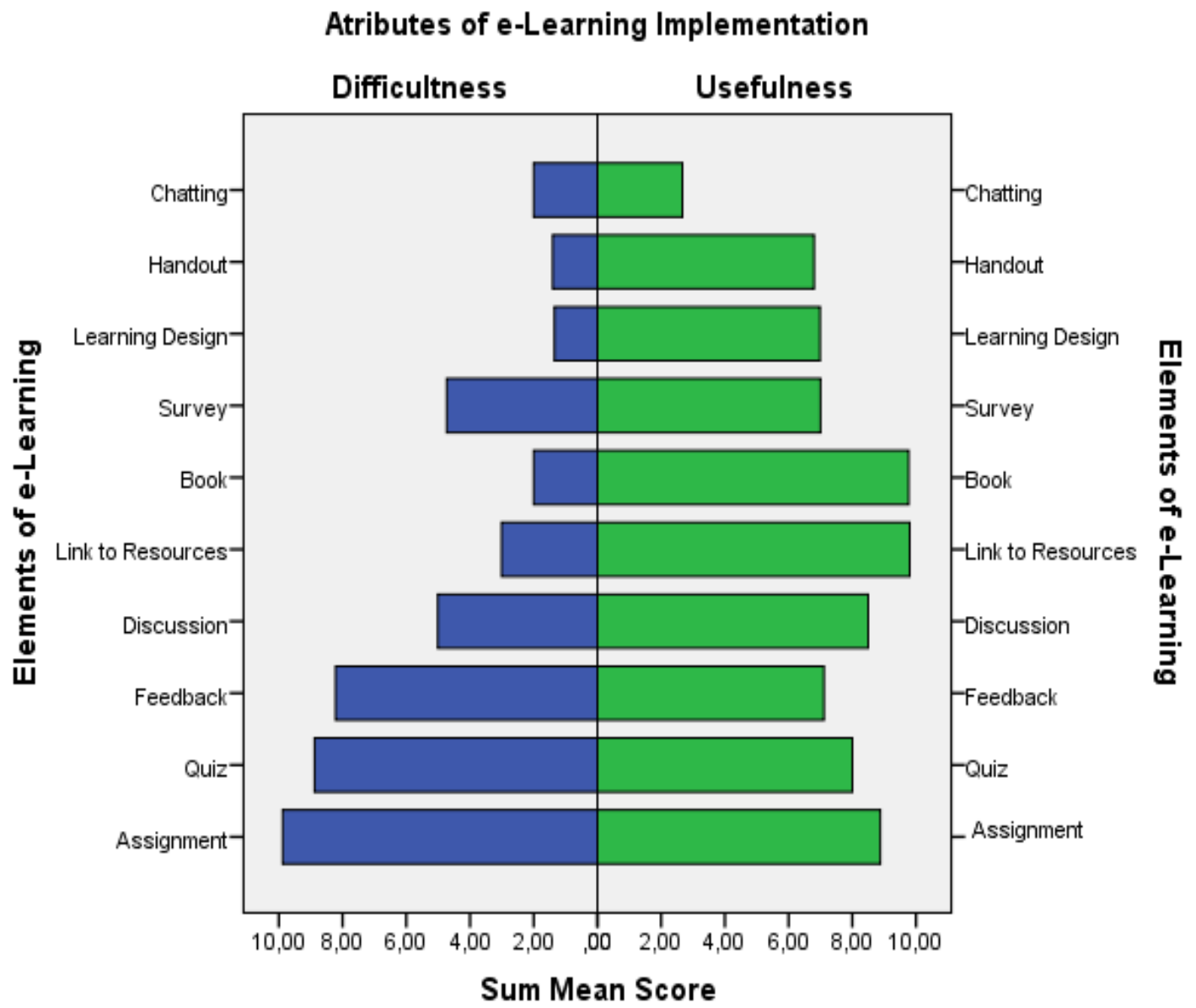

Gambar 1. The Rank of Mean Score Based on Range

\section{Penarikan kesimpulan dan pengahuan rekomendasi}

Berdasarkan hasil analisis data terlihat bahwa range terbesar (posisi paling bawah dalam piramida) adalah "assignment". Dengan demikian, "asssignment" merupakan tersebut elemen yang menempati prioritas pertama dalam upaya perbaikan e-learning pendidikan tenaga kesehatan tersebut, lalu diikuti secara berurutan yaitu quiz, feedback, discussion, link to resources, book, survey, learning design, handout, and chatting. Mengacu kepada urutan tersebut, maka direkomendasikan bahwa 5 elemen dengan range terbesar (assingnment, quiz, feedback, discussion and link to resources) diprioritaskan untuk diperbaiki terlebih dahulu, sedangkan 5 elemen dengan range terkecil (book, book, survey, learning design, handout and chatting) bisa diperbaiki kemudian.

\section{PEMBAHASAN}

Penelitian ini menyuguhkan metode baru dalam penentuan langkah awal bagi upaya untuk prbaikan kualitas e-learning pendidikan tenaga kesehatan. Pada langkah pertama (penentuan elemen-elemen e-learning) telah dipilih sepuluh elemen yang mengacu kepada program-program e-learning yang paling sering digunakan yaitu 
learning design, handout, book, link to resources, discussion forum, chatting, assignment, feedback, quiz and survey. Pemilihan ini telah dilakukan dengan hati-hati yaitu merujuk kepada sumber informasi yang kredibel yaitu software-software yang terpilih untuk dimasukkan di dalam Softaculous, suatu pengorganisir software yang dipakai oleh $c$ Panel sebagai program pengelolaan website yang terkemuka. ${ }^{(3)}$

Pada langkah kedua yaitu pemilihan atribut-atribut penilaian sebagai dasar penentuan prioritas telah terpilih dua atribut yaitu difficultness dan usefulness. Kedua atribut tersebut telah dipilih berdasarkan pertimbangan secara seksama melalui literature revew. Karena e-learning merupakan salah satu bagian dari implementasi sistem berbasis TIK, maka telah diputuskan untuk dilakukan penelusuran tentang determinan-determinan utama bagi penerimaan TIK oleh para pengguna. Merujuk kepada Technology Acceptance Model (TAM) dalam tiga generasi ${ }^{(5),(6),(7)}$ sebagai salah model penerimaan teknologi yang paling banyak digunakan ${ }^{(4)}$, maka pemilihan dua determinan tersebut dipertimbangkan sebagai langkah yang tepat. Setelah melalui proses diskusi yang melibatkan para pakar dari "Humanistic Network for Science and Technology" selanjutnya dilakukan sedikit perubahan terminologi yaitu dari "ease of use" menjadi "difficultness". Langkah ini bagus karena terminologi baru ini lebih mudah diterapkan dalam praktik.

Pada langkah ketiga yaitu pemilihan elemen-elemen yang diprioritaskan, telah diputuskan bahwa "difficultness" merupakan atribut yang harus diturunkan nilainya sehingga harus diberi skor dengan tanda negatif; sedangkan "usefulness" adalah atribut yang harus ditingkatkan nilainya sehingga harus diberi skor dengan tanda positif. Jika disajikan dalam bentuk diagram, perbedaan cara pemberian skor bagi dua atribut ini akan menghasilkan batang-batang ke arah kiri untuk "difficultness" dan batang-batang ke arah kanan untuk "usefullness". Dalam hal ini yang diprioritaskan adalah elemen yang memiliki nilai total "difficultness" dan "usefullnes" terbesar atau dengan kata lain adalah elemen dengan range terbesar yang dimulai dari nilai "difficultness" sampai dengan "usefulness". Penggunaan diagram dalam bentuk piramida ini dimaksudkan agar hasil analisis dapat dipahami dengan cepat. Berkaitan dengan hal ini, para pakar yang terlibat dalam diskusi memberikan apresiasi positif bahwa analisis dan penyajian berupa piramida ini merupakan pilihan yang bagus. Dalam hal ini, piramida dapat dibuat secara manual atau menggunakan statistical software seperti SPSS, dengan memanfaatkan fasilitas pembuatan piramida penduduk ${ }^{(8)}$, dengan catatan yaitu: 1) "variable" form diisi dengan mean score, 2) "show distribution over" form diisi dengan elements of $e$ learning, 3) "split by" form diisi dengan attributes of e-learning.

Pada langkah keempat yaitu uji coba di lapangan, elemen-elemen e-learning berhasil diurutkan mulai dari yang paling membutuhkan perbaikan segera. Dalam hal ini, setelah disusun secara berurutan mulai dari nomor 1 sampai dengan nomor 10 , elemen-elemen tersebut juga dipandang perlu untuk dibagi menjadi dua kelompok besar, dengan maksud agar upaya perbaikan elemen bisa diorganisir dengan lebih mudah, misalnya tahap pertama untuk 5 elemen dengan nilai prioritas tertinggi dan tahap kedua untuk 5 elemen dengan nilai prioritas terendah.

Pada tahap kelima, penarikan kesimpulan dapat dilakukan dengan mudah karena hasil analisis data sudah disajikan secara visual dalam bentuk piramida. Dalam hal ini, elemen pada posisi paling bawah adalah prioritas pertama, lalu secara berurutan diikuti oleh elemen di atasnya, dan elemen paling atas adalah prioritas terakhir. Rekomendasi juga bisa disampaikan dengan mudah karena cukup merujuk kepada urutan prioritas yang telah didapatkan dalam kesimpulan penelitian. Berdasarkan kesimpulan dan 
rekomendasi ini, para pengelola e-learning dapat segera menyusun rencana perbaikan elemen sesuai dengan karakteristik dari elemen-elemen tersebut.

Keseluruhan proses di atas merupakan upaya yang diarahkan untuk meningkatkan kualitas e-learning pendidikan tenaga kesehatan. Fokus dari metode baru yang sederhana ini adalah visualisasi hasil analisis data dalam bentuk "PIRAMIDA" sehingga sangat mudah untuk dipahami. Selanjutnya piramida ini diperkenalkan dengan nama "DIFFICULTNESS-USEFULNESS PYRAMID" yang disebut dengan nama singkat "DUP"

Perlu dicatat bahwa dalam penelitian ini, "e-learning pendidikan tenaga kesehatan" adalah contoh dari suatu obyek yang akan menjadi sasaran upaya peningkatan kualitas. Dengan demikian, terbuka peluang untuk menerapkan keseluruhan dari proses ini untuk obyek-obyek yang lain, misalnya sistem infomasi rumah sakit, telemedicine, sistem informas puskesmas, e-Health, e-journal kesehatan dan sebagainya. Tentu saja peneliti terlebih dahulu harus memilih elemen-elemen yang relevan dengan obyek tersebut. Selain merujuk kepada literatur yang telah mapan, elemen-elemen terkait juga bisa digali dari para pengguna sistem yang akan digarap, misalnya melalui focused group discussion atau brainstorming.(9)

\section{CONCLUSION}

Penelitian ini telah menghasilkan sebuah metode baru yang bisa diterapkan dengan mudah untuk memilih komponen-komponen yang diprioritaskan dalam upaya perbaikan e-learning pendidikan tenaga kesehatan. Temuan ini diharapkan akan berkontribusi secara positif dalam upaya peningkatan kualitas manajemen pendidikan tenaga kesehatan dan juga bisa dikembangkan bagi sistem-sistem kesehatan yang lain.

\section{CONFLICT-OF-INTEREST}

Para penulis menyatakan bahwa tidak ada conflict of interest berkaitan dengan penelitian ini.

\section{SUMBER BIAYA}

Semua pembiayaan penelitian bersumber dari seluruh anggota tim peneliti.

\section{REFERENSI}

1. Nugroho HSW, Supriyanto S, Notobroto HB. The role of perceived organizational support, personal characteristic and perceived enjoyment in acceptance model of maternal and child health information systems. Airlangga University; 2016.

2. Nugroho HSW. The application of classroom action research (CAR) in health education (Aplikasi penelitian tindakan kelas (PTK) dalam pendidikan kesehatan). 1st ed. Sunarto, editor. Ponorogo: Forum Ilmiah Kesehatan (FORIKES); 2017.

3. Tutorials Point. cPanel Tutorial [Internet]. Tutorials Point, Simply Easy Learning. 2107 [cited 2018 Jan 3]. Available from: https://www.tutorialspoint.com/cpanel

4. Surendran P. Technology Acceptance Model : A survey of literature. Int J Bus Soc Res. 2012;2(4):175-8.

5. Davis FD, Bagozzi RP, Warshaw PR. User acceptance of computer technology: a 
comparison of two theoretical models. Manage Sci. 1989;35(8):982-1003.

6. Venkatesh V, Davis F. Theoretical extension of the Technology Acceptance Model: Four longitudinal field studies. Manage Sci. 2000;46(2):186-204.

7. Venkatesh V, Bala H. Technology Acceptance Model 3 and A Research Agenda on Interventions. Decis Sci [Internet]. 2008;39(2):273-315. Available from: http://onlinelibrary.wiley.com/doi/10.1111/j.1540-5915.2008.00192.x/pdf

8. IBM Knowledge Center. Obtaining population pyramids [Internet]. 2018 [cited 2018 Jan 4]. Available from: https://www.ibm.com/support/knowledgecenter/en/SSLVMB_24.0.0/spss/base/idh_i dd_population_pyramid.html

9. Nugroho HSW. Quality of health service according to consumer perception (Kualitas layanan kesehatan menurut persepsi konsumen. 1st ed. Sunarto, editor. Magetan: Forum Ilmiah Kesehatan (FORIKES); 2011. 